\title{
LAPORAN PERTAMA SPESIES KUTU Craspedorrhynchus platystomus DARI ELANG ULAR BIDO (Spilornis cheela bido) DI BANYUWANGI
}

\section{First report of the chewing lice species of Craspedorrhynchus platystomus from Crested Serpent Eagle (Spilornis cheela bido) in Banyuwangi}

\author{
Aditya Yudhana ${ }^{1 *}$, Ratih Novita Praja ${ }^{2}$ \\ ${ }^{1}$ Department of Parasitology, \\ ${ }^{2}$ Department of Microbiology, \\ Faculty of Veterinary Medicine, Universitas Airlangga, \\ UNAIR C-Campus Mulyorejo, Surabaya, Jawa Timur, Indonesia, 60115 \\ Telp. (031)5993016, Fax. (031)5993015 \\ *Corresponding author: adityayudhana@fkh.unair.ac.id
}

\begin{abstract}
Abstrak
Ectoparasit seperti kutu dapat memainkan peran penyebaran penyakit antar hewan, ini bisa lebih buruk jika ektoparasit bertindak sebagai vektor. Hilangnya mulai dari penurunan berat badan, penurunan produksi, rambut rontok atau bulu, trauma, iritasi, anemia, hingga kematian dan sering terjadi pada hewan liar di hutan. Belum ada penelitian yang menjelaskan sebelumnya tentang infestasi kutu pada elang ular bido (Spilornis cheela bido) di Banyuwangi. Penelitian ini bertujuan untuk melaporkan infestasi kutu yang dikumpulkan dari elang ular bido di Banyuwangi. Elang ular bido diperiksa dengan hati-hati untuk mengambil kutu pada permukaan tubuh, hanya satu spesies kutu yang diamati yaitu Craspedorrhynchus platystomus. Spesies lain dari ektoparasit tidak diisolasi dari elang yang terinfestasi selama periode penelitian.
\end{abstract}

Kata kunci: elang ular bido, Craspedorrhynchus platystomus, Banyuwangi

\begin{abstract}
Ectoparasites such as lice can play a role spread of disease between animals, this can be even worse if ectoparasites acting as vector. The losses starting from decreased body weight, decreased production, hair loss or fur, trauma, irritation, anemia, until death and often occurs on wild animals in the forest. There is no previous described research on lice infestation of Crested Serpent eagle (Spilornis cheela bido) in Banyuwangi. This research aim to first report of lice infestation collected from Crested Serpent eagle in Banyuwangi. Crested Serpent eagle were examined carefully for chewing lice on the body surfaces, only one lice species was observed namely Craspedorrhynchus platystomus. Another species of ectoparasites were not isolated from the infested eagle during the research period.
\end{abstract}

Key words: crested serpent eagle, Craspedorrhynchus platystomus, Banyuwangi

\section{INTRODUCTION}

The Crested Serpent eagle (Spilornis cheela bido) is a medium-sized bird of prey found in the tropical rain forest and forest fringe. This species has a wide range of habitats across its range, which spans the Indian subcontinent and southern Asia (Lekagul and Round, 2005).

The Crested Serpent eagle is known as a large bird of prey, it has strong flying ability, wide wings, large and sharp bill, as well as strong nails. The eagle also has sharp eyesight for see the prey from a great distance. With this ability, the eagles are at the top of the food chain on ecosystems. The position in the food chain acts as a balancing ecosystem for other animals at the bottom of the food chain so that the amount is not excessive (Black et al., 2013).

Ectoparasites are a classic adverse problem, but they are not got good attention. The losses incurred are huge, starting from decreased body weight, decreased production, hair loss or fur, trauma, irritation, anemia, until death. The problem often occurs on farms until wild animals in the forest. This will have an adverse effect on 
the number of wildlife populations. Ectoparasites control is not an easy thing to do and take time many years. Ectoparasites can play a role spread of disease between animals (Irwin, 2002).

This can be even worse if in a place as an endemic region of a disease and ectoparasites acting as vector. The ectoparasites may be flies, mosquitoes, lice, fleas, ticks, and mites. Its role as ectoparasites is not the same, depending on the stage of development and behavior. In addition, ectoparasites can transmit disease from animals to humans (Dik and Halajian, 2013).

This is what needs to be studied further because research on ectoparasites in wild animals have not been widely practiced. The tropical climate in Indonesia is one of the supporting factors of many types of ectoparasites infested in pets, farm, or wild animals. The types of ectoparasites in Crested Serpent eagle (Spilornis cheela bido) has not been recorded in detail and also has not been studied before especially lice.

Therefore, this study aims to identify the types of lice present in Crested Serpent eagle and spread its infestation in some ex-situ habitats in Indonesia. The benefit of this study is to provide information for the development of science, especially from ectoparasites in the wilds is currently not getting much attention from researchers before. This study is also expected to be further development program for ectoparasites control in wild animals.

\section{MATERIAL AND METHODS}

A Collection of eagles are kept in Nature Conservation Agency, Banyuwangi Region, Indonesia. Lice were collected from the 10 Crested Serpent eagle, kept in semi open area in the captivity. In order to collect the lice, eagle were examined on the body surfaces between October and December 2017. All lice were collected from the feathers of the head and neck of the birds and placed in tubes with $70 \%$ alcohol, then cleared in $(\mathrm{KOH}) 10 \%$ and fixed in Canada balsam (Palma, 1978).

The lice were identified based on morphological key described by Price et al.
(2003); Wall et al. (2001); Nasser et al. (2014). Collected species have been deposited in the Laboratory of Parasitology, Faculty of Veterinary Medicine, Universitas Airlangga PSDKU Banyuwangi.

\section{RESULTS AND DISCUSSION}

Lice species was commonly observed on the feathers of the head and neck part of the birds. 40 samples collected from the infested eagle. The results of microscopic examination performed on the lice species of Crested Serpent eagle, researcher found one species were identified, namely Craspedorrhynchus platystomus (Fig.1).

They are large lice, about $2-3 \mathrm{~mm}$ in length. The following morphologic features were noted and recorded: The head is large, trapezoidal in shape and well chitinised. The anterior margin of the head is slightly invaginated in its medial aspect.

The hyaline margin was clearly emarginated while the marginal carina was interrupted medially and laterally. Mandibles well developed and notched medially on the occlusal surface. Labrum covered by the mandibles and not visible. The antennae have 5 segments. Two proximal ones (scape and pedicel) wider than the third; fourth and fifth (flagellomeres) taper noticeably towards the apical end.

The thorax (prothorax and pterothorax) of both sexes relatively small without thoracic spiracle noted due to the viewing angle. The prothorax diamond-shaped under microscope, and pterothorax slightly wider than prothorax.

The legs are short and well developed. First pair of legs shorter than second and third pairs. The legs terminate into 2 strong tarsal claws with 3 stout, interdigitating, appositional, thumb-like spines. The dorsoventrally flattened abdomen is well chitinised in the lateral. Paratergal plates well sclerotised and triangular in shape. Long setae are observed in tufts, laterally placed on the abdominal segments, especially concentrated on the central surface as well. This species is reported for the first time from Crested Serpent eagle in Banyuwangi, Indonesia. 
Table 1. Measurements of Craspedorrhynchus platystomus from crested serpent eagle in Banyuwangi (ranges in $\mathrm{mm}$ )

\begin{tabular}{ccccc}
\hline Cephalic Length & Cephalic Width & Thoracic Length & Abdominal Length & Total Length \\
\hline 0.96-1.00 & $0.98-0.99$ & $0.52-0.56$ & $1.09-1.27$ & $2.60-2.79$ \\
\hline
\end{tabular}

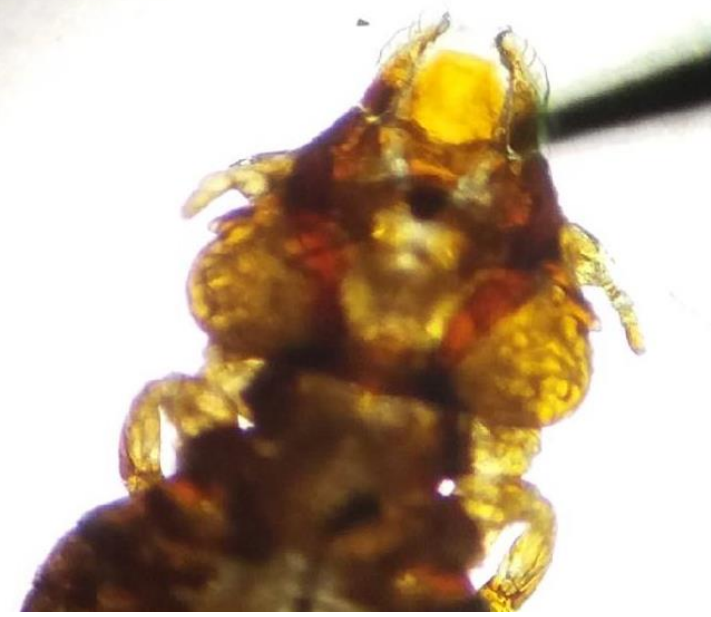

(a)

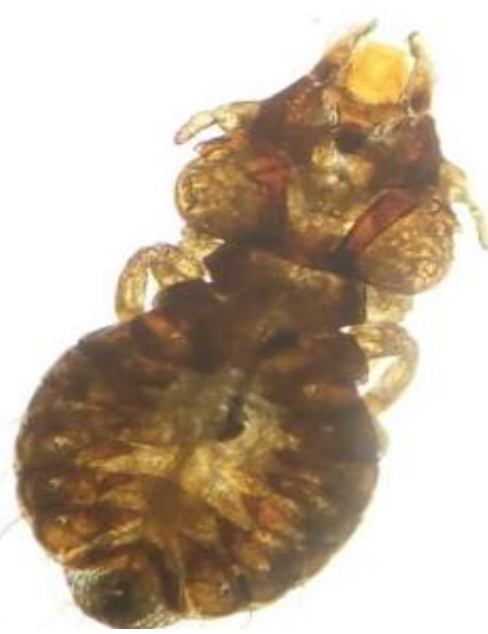

(b)

Figure 1. Craspedorrhynchus platystomus collected from crested serpent eagle (Spilornis cheela bido) in Banyuwangi. (a) Enlarged the cephalic part; (b) The complete segment of anterior and posterior

It is important to consider that external parasites in birds cause feather loss, irritation, injury, nervousness, pruritus and reduction in production rather than their role as vector (Wall et al., 2001, Marco Antonio et al., 2014). The ischnoceran genus Craspedorrhynchus exclusively parasitises raptors (Accipitriformes) (Mey, 2001), except for vultures (Perez and Martin-Mateo, 1995).

The diversity of this apparently morphologically uniform ischnoceran group has been very poorly studied (Mey, 2001). In Craspedorrhynchus spp., the premarginal and ventral carinae of the forehead reach farther anteriorly than the dorsal anterior plate (clypeal plate). The clavi are well developed (Perez and Martin-Mateo, 1995).

Morphological characteristics of $C$. platystomus have previously only been studied by light microscope. The anterior borders of the clypeus formed folds, which created a notch at their tip on either side. This feature could assist in the attachment to a feather. The mandibles were broad, flattened, and deeply notched on the cutting edges, seemingly adapted to the cutting of feathers as well as being suited to scraping dry, flaky, exfoliated cells off the skin of the host (Dik, 2006).

Khan et al. (2011) reported that the antennal flagellum of the female showed tactile setae and chemoreceptors which was collected from the black kite, Milvus migrans. These types of receptors were all previously described in studies performed on insects from other orders. However, no reports were made concerning the sensilla basiconica.

Perez and Martin-Mateo (1995) also reported that sensilla basiconica were present on the antennae of louse species. They stated that basiconic sensilla were distinguishable from the trichoid ones by the thicker aspect of their projected portion.

Perez and Martin-Mateo (1995) recorded that the thickness of the cuticular wall of the Sensilla basiconica was variable, and 4 relatively long and 7 short Sensilla basiconica were detected on the apical end of the antenna of $C$. platystomus, which was the case in this study as 
well. Sensilla coeloconica were not observed in the specimens during our examination due to a covering of natural fats, oils, and waxes. There have been studies on infestation with lice in passerine birds, greatwhite pelican (Pelecanus onocrotalus), golden eagles and other wild bird species in Iran, there is no record of this louse species from this bird orders (Tavassoli et al., 2011; Dik and Halajian, 2013 ; Moodi, 2013; Azizi et al., 2013).

Additionally, five lice species (Lipeurus caponis, Menopon gallinae, Menacanthus stramineus, Goniodes dissimilis and Cuclotogaster heterographus) have been reported from chicken in Golestan Province, northern Iran (Eslami et al., 2009).

Dik et al. (2013) also found C. platystomus on long-legged buzzard in northwestern Turkey and reported for the first time in Turkey. Naz et al. (2012) published the chewing lice (Phthiraptera) of Columbidae (Columbiformes) from neighbor country Pakistan, but did not report $C$. platystomus on crested serpent eagle.

\section{CONCLUSION}

Except from these research, the knowledge of lice species on crested serpent eagle in Banyuwangi, Indonesia remains limited. There was no previous targeted research on lice infestation of eagle. We report for the first time in this research louse on crested serpent eagle in Banyuwangi, Indonesia. Considering that there is limited information available on the louse of eagle, further research are needed to identify and comprise future collections of lice. However, SEM could be used in differential diagnosis of species that have highly similar morphological characteristics as well as in specialised micromorphology and morphometrics.

\section{ACKNOWLEDGEMENTS}

The financial support of the Universitas Airlangga Research and Development Institute to the first author made this study possible. It was also partially supported by the Faculty of
Veterinary Medicine. All team in PSDKU Banyuwangi which involve in this research.

\section{REFERENCES}

Azizi, H.R., M. Adel, E. Sayahi, A.K. Zamani Moghadam, A. Esmailian Dehkordi and M. Hematzadeh. 2013. Laemobothrion maximum (chewing lice) in Iranian Golden Eagles. J Anim Poultry Sci, 2(3): 85-90.

Black, P.A., D.L. McRuer, and H.A. Horne. 2013. Hematologic parameters in raptor species in a rehabilitation setting before release. J. Avian Med. Surg, 25: 192-198.

Dik, B. 2006. Mallophaga species on longlegged buzzards (Buteo rufinus): new records from Turkey. Türkiye Parazitol. Derg, 30: 226-230.

Dik, B and A. Halajian. 2013. Chewing lice (Phthiraptera) of several species of wild birds in Iran, with new records. $J$ Arthropod Borne Dis, 7(1).235-237.

Dik, B., A. Halajian, M. Turner. 2013. The morphology of Craspedorrhynchus platystomus (Burmeister, 1838), a louse commonly found on the long-legged buzzard Buteo rufinus (Phthiraptera: Ischnocera: Philopteridae). Turk J Zool, 37: 739-745.

Eslami, A., P. Ghaemi and S. Rahbari. 2009. Parasitic infections of free range chickens from Golestan Province, Iran. Iranian $J$ Parasitol, 4(3): 10-14.

Irwin, P.J. 2002. Companion animal parasitology: a clinical perspective. Int $J$ Parasitol, 32: 581-593.

Khan, V., N. Bansal, G. Arya, A. Ahmad and A.K. Saxena. 2011. Contribution to the morphology of Degeeriella rega Lekagul, B. and Round, P. D. 2005. A Guide to the Birds of Thailand. pp. 72-76, Darnsutha Press, Bangkok. 
Marco Antonio, C., A. Jaime, A.S. Narciso Tsac, M.P. Jerez- Salas, B. Edgar and J.C. Lopez. 2014. Ectoparasites and their damage in Backyard Turkeys in oaxaca's coast, Mexico. EJVM, 7: 1-14.

Mey, E. 2001. A new Craspedorrynchus species (Phthiraptera, Ischnocera) from Australia, with an annotated checklist of this louse genus. Mitt. Mus. Nat. kd. Berl., Dtsch. entomol. Z, 48: 117-132.

Moodi, B., M. Aliabadian, A. Moshaverinia and O. Mirshamsi Kakhki. 2013. New data on the chewing lice (Phthiraptera) of passerine birds in East of Iran. Sci Parasitol, 14(2):6368.

Nasser, M., A. AL-Ahmed, M. Shobrak and Y. Aldryhim. 2014. Identification key for chewing lice (Phthiraptera: Amblycera, Ischnocera) infesting the Indian Peafowl (Pavo cristatus) with one new country record and new host record for Saudi Arabia. Turk J Zool, 38.

Naz, S., O. Sychra and S.A. Rizvi. 2012. New records and a new species of chewing lice (Phthiraptera, Amblycera, Ischnocera) found on Columbidae (Columbiformes) in Pakistan. Zoo Keys, 174: 79-93.
Palma, R.L. 1978. Slide-mounting of lice: a detailed description of the Canada balsam technique. New Zeal Entomol, 6(4): 432-436.

Perez, J.M. and M.P. Martin-Mateo. 1995. First description of male Craspedorrhynchus subbuteonis Gallego, Martin \& Aguirre, 1987 (Phthiraptera: Ischnocera: Philopteridae). Ann. Soc. Entomol. Fr, (NS) 31: 285-291.

Price, R.D., R.A. Hellenthal, R.L. Palma, K.P. Johnson, and D.H. Clayton. 2003. The Chewing Lice: World Checklist and Biological Overview. Illinois Natural History Survey Special Publication, Champaign, IL, USA.

Tavassoli, M., R. Salmanzadeh and H. Jabbari. 2011. Infestations of Piagetiella titan (Menoponidae: Mallophaga) on juvenile white pelicans (Pelecanus nocrotalus, L.) in Urmia Lake National Park, northwest Iran. Int. J Vet Res, 5:105.

Wall, R and D. Shearer. 2001. Veterinary Ectoparasites second edt. Blackwell Science; 123-126. 